\title{
Growth of Falcataria moluccana and Albizia chinensis seedling under aluminum exposure
}

\author{
MOHAMMAD AGUS SALIM ${ }^{1, \vartheta}$, LULUK SETYANINGSIH $^{2}$, IMAM WAHYUDI ${ }^{3}$, SRI WILARSO BUDI ${ }^{4, \bullet \varphi}$ \\ ${ }^{1}$ Program of Tropical Silviculture, Department of Silviculture, Faculty of Forest and Environment, Institut Pertanian Bogor. Jl. Lingkar Akademik, Bogor \\ 16680 West Java, Indonesia. Tel.: +62-251-8626806, Fax.: +62-251-8626886, `email: moch_agussalim@apps.ipb.ac.id, agussalim.ipb@gmail.com. \\ ${ }^{2}$ Faculty of Forest, Universitas Nusa Bangsa. Jl. Kh. Sholeh Iskandar Km 4, Bogor 16166, West Java, Indonesia \\ ${ }^{3}$ Departemen of Forest Product, Faculty of Forest and Environment, Institut Pertanian Bogor. Jl. Lingkar Akademik, Bogor 16680 West Java, Indonesia \\ ${ }^{4}$ Department of Silviculture, Faculty of Forest and Environment, Institut Pertanian Bogor. Jl. Lingkar Akademik, Kampus IPB Dramaga, Bogor 16680 \\ West Java, Indonesia. Tel.: +62 2518626806, Fax.: +62 251 8626886, ^vemail: wilarso62@ yahoo.com
}

Manuscript received: 27 July 2021. Revision accepted: 13 August 2021.

\begin{abstract}
Salim MA, Setyaningsih L, Wahyudi I, Budi SW. 2021. Growth of Falcataria moluccana and Albizia chinensis seedling under aluminum exposure. Biodiversitas 22: 3694-3702. Aluminum (Al) is an element found in acid soils and is one of the limiting factors for plant growth. This study aims to examine the growth of Falcataria moluccana (Miq.) Barneby \& J.W.Grimes and Albizia chinensis (Osbeck) Merr seedlings underexposure of aluminum. This study used an one-factor completely randomized design (Al concentration) consisting of 5 levels, namely $0,2,4,6$, and $8 \mathrm{mM}$. Each treatment was repeated 3 times and each replication consisted of 3 plant units. The results showed that the $\mathrm{Al}$ exposure treatment gave significant differences in the growth of height, root length, dry weight (root, shoot, and total) of $F$. moluccana and A. chinensis seedlings. The $2 \mathrm{mM} \mathrm{Al}$ concentration stimulated the growth of height, root length and dry weight (root, shoot, and total) of A. chinensis seedlings. The tolerance index for $F$. moluccana and $A$. chinensis seedlings was highest when the $\mathrm{Al} 2 \mathrm{mM}$ concentration was $147.55 \%$ and $115.32 \%$, respectively. $2 \mathrm{mM}$ Al exposure treatment increased the chlorophyll content $\mathrm{a}, \mathrm{b}$, total chlorophyll and carotenoids of $F$. moluccana and $A$. chinensis seedlings. Al exposure treatment did not significantly differ from the rate of photosynthesis and MDA content in $F$. moluccana and A. chinensis seedlings. The $\mathrm{Al}$ content in the roots was higher than in the shoots, and the increase in $\mathrm{Al}$ concentration increased the $\mathrm{Al}$ content in the roots and shoots of $F$. moluccana and A. chinensis seedlings.
\end{abstract}

Keywords: Aluminum, concentration, increase, seedlings, stimulated

\section{INTRODUCTION}

One of the elements found in acid soils is aluminum. Generally, Al toxicity occurs on acid soils when the $\mathrm{pH}$ is below 5, Al solubility increases (Al toxicity increases) (Lilienfein et al. 2003; Silva 2012). Aluminum is very soluble at soil $\mathrm{pH}(<5)$ and is a limiting factor in plant growth (Panda et al. 2009; Nunes-Nesi et al. 2014; Singh et al. 2017). Al toxicity in acid soils has harmed plant growth and production ( $\mathrm{Yu}$ et al. 2011; Pattanayak and Pfukrei 2013). Al toxicity can inhibit root growth and development, thus inhibiting the absorption of water and nutrients that impact inhibiting plant growth (Konarska 2008; Böhlenius et al. 2018). In addition, Al toxicity is capable of causing oxidative stress due to the accumulation of reactive oxygen species (ROS), which later affects the physiological processes and metabolism of plants (Inostroza-Blancheteau et al. 2012). Al toxicity is available in $\mathrm{Al}^{3+}$ (Liu et al. 2014; Schmitt et al. 2016). When dissolved $\mathrm{Al}^{3+}$ levels reach 10 $20 \mathrm{mg} / \mathrm{kg}$ or more, they can cause a toxic effect on plants (Kochian et al. 2004). Even according to Balsberg et al. (1990) Al concentrations of more than 2-3 ppm at soil $\mathrm{pH}$ of 5.5 can poison plants.

Falcataria moluccana (Miq.) Barneby \& J.W.Grimes and Albizia chinensis (Osbeck) Merr are species belonging to the Fabaceae family. Both species are included in the fast- growing species (Hughes and Uowolo 2006), which have quite high economic value (Yuskianti and Shiraishi 2017). So, they are widely cultivated, especially in Indonesia (Widyastuti et al. 2013). In addition, the F. moluccana and A. chinensis is quite essential in Southeast Asian countries (Aiso et al. 2016). The species of $F$. moluccana is also a species that is widely used in forest rehabilitation programs including in post mine areas (Prematuri et al. 2020), especially in Indonesia. Species of $F$. moluccana and $A$. chinensis are also commonly planted in agroforestry systems (Uddin et al. 2008; Sarimah et al. 2018). Species of the Fabaceae family can have symbiosis with rhizobium bacteria, so that they can fix nitrogen in the atmosphere (Hughes et al. 2012; Arunakumara et al. 2013). This study aims to examine the growth of $F$. moluccana and A. chinensis seedlings against exposure to aluminum, and to examine the resistance of each species of seedling to exposure to Al.

\section{MATERIALS AND METHODS}

Germination of seeds. The breaking of the seed dormancy of $F$. moluccana and $A$. chinensis was done by soaking in hot water $\left(80{ }^{\circ} \mathrm{C}\right)$ for 15 minutes and then soaked in water $\left(25-30{ }^{\circ} \mathrm{C}\right.$ ) for 24 hours (Alghofar et al. 2017). After that, the seeds are sown in a tub of sprouts that 
already contain zeolite media. The seeds are maintained for \pm 14 days until the seeds are ready for weaning.

Media preparation. The media used in this research was water culture. The nutrient solution used refers to the nutrient solution developed by Sopandie (1999), consisting of: $1.5 \mathrm{mM} \mathrm{Ca}\left(\mathrm{NO}_{3}\right)_{2} .4 \mathrm{H}_{2} \mathrm{O}, 1.0 \mathrm{mM} \mathrm{NH} \mathrm{NO}_{3}, 1.0 \mathrm{mM}$ $\mathrm{KCl}, 0.4 \mathrm{mM} \mathrm{MgSO} 4.7 \mathrm{H}_{2} 0,1.0 \mathrm{mM} \mathrm{KH_{2 }} \mathrm{PO}_{4}, 0.50 \mathrm{ppm}$ $\mathrm{MnSO}_{4} \cdot \mathrm{H}_{2} \mathrm{O}, \quad 0.02 \mathrm{ppm} \quad \mathrm{CuSO}_{4} .5 \mathrm{H}_{2} \mathrm{O}, \quad 0.05 \mathrm{ppm}$ $\mathrm{ZnSO}_{4} .7 \mathrm{H}_{2} \mathrm{O}, \quad 0.50$ ppm $\mathrm{H}_{3} \mathrm{BO}_{3}, \quad 0.01$ ppm $\left(\mathrm{NH}_{4}\right)_{6}$ $\mathrm{Mo}_{24} \mathrm{O}_{24} \cdot 4 \mathrm{H}_{2} \mathrm{O}$. For $\mathrm{Al}$ exposure using $\mathrm{AlCl}_{3}$.

Seedling adaptation test and $\mathrm{Al}$ exposure treatment experiment. The seedlings ready to be weaned are transferred to the tub that already contains the media. During the adaptation test, the seedlings were kept for 14 days. Each seedling is placed on the serophome that has been perforated. The stems of the seedlings are wrapped in cotton so that the seedlings can stand upright. After the adaptation test, the seedlings were transferred again to a container that already contained media that had been treated with predetermined concentrations of $\mathrm{Al}(0,2,4,6$, and $8 \mathrm{mM}$ ). During the adaptation test and treatment experiment, the media was maintained at $\mathrm{pH} 4$. The $\mathrm{pH}$ adjustment was carried out by adding $1 \mathrm{~N} \mathrm{HCl}$ and $1 \mathrm{~N}$ $\mathrm{KOH}$. The addition of media was carried out when the media volume had begun to decrease. The media is replaced after 14 days to keep seedling growth optimal. Seedlings are maintained for up to 28 days.

Evaluate parameters. Growth parameters measured included: plant height, root length, root and shoot dry weight. Plant height was measured every week for four weeks, while root length was measured at week 4 . The photosynthetic rate was measured using a Licor (Li-6400 XT) portable photosynthesis system in the morning (09.00-11.00). Plants were harvested after 30 days, the roots and shoots were separated and oven for two days at $80{ }^{\circ} \mathrm{C}$. After that, the plant samples were weighed to obtain the root and shoot dry weight. The seedling tolerance index was calculated using the equation from Liu and Ding (2008), as follows:

Tolerance index $=\frac{\text { Total dry weight of plants treated with } \mathrm{Fe}}{\text { Total dry weight of plants not treated with } \mathrm{Fe}(\text { control) }} \times 100 \%$

Analysis of chlorophyll and carotenoid content. Chlorophyll and carotenoid content refer to Sims and Gammon (2002) with modifications. Leaf samples 0.03$0.05 \mathrm{~g}$ were crushed using a mortar until smooth by adding $2 \mathrm{ml}$ of acetone (85: 15\%, Trs $\mathrm{HCl} \mathrm{1 \% ,} \mathrm{pH} \mathrm{8)} \mathrm{and}$ centrifuged at $10,000 \mathrm{rpm}$ for 5 minutes. Take $1 \mathrm{ml}$ of supernatant and add $3 \mathrm{ml}$ of tris acetone, then shake until homogeneous. The absorbance was measured at wavelengths $(\lambda)$ 470, 537, 647, and $663 \mathrm{~nm}$ and was measured using a UV-VIS spectrophotometer. Chlorophyll and carotenoid values are expressed in $\mathrm{mg} / \mathrm{g}$. Chlorophyll and carotenoid content are determined based on the equation Sims and Gamon (2002).

\footnotetext{
Anthocyanin $=0.08173 * \mathrm{~A}_{537}-0.00697 * \mathrm{~A}_{647}-0.002228 * \mathrm{~A}_{663}$ $\mathrm{Chl}_{\mathrm{a}}=0.01373 * \mathrm{~A}_{663}-0.000897 * \mathrm{~A} 537-0.003046 * \mathrm{~A}_{647}$ $\mathrm{Chl}_{\mathrm{b}}=0.02405 * \mathrm{~A} 647-0.004305 * \mathrm{~A} 537-0.005507 * \mathrm{~A} 663$ Carotenoids $=\frac{(\text { A470 }-(17.1 *(\text { Chla }+ \text { Chlb })-9.479 * \text { Anthocianin }))}{}$
}

Where, Ax is the absorbance at the measured wavelength.

MDA lipid peroxide analysis. Lipid peroxide analysis refers to Siska et al. (2017) with modifications. Leaf samples of $0.03-0.05 \mathrm{~g}$ were crushed with a mortar, then added $5 \mathrm{ml}$ of $0.1 \%(\mathrm{w} / \mathrm{v})$ trichloroacetic acid (TCA) and centrifuged at $10,000 \mathrm{~g}$ for 5 minutes. After that, $1 \mathrm{ml}$ of the supernatant was transferred to a new tube and $4 \mathrm{ml}$ of $0.1 \%$ (w / v) thiobarbituric acid (TBA) was added in $20 \%$ (w / v) TCA. The solution was incubated at $80 \mathrm{oC}$ in a water bath for 30 minutes, and then cooled to room temperature. The absorbance of the TBA-MDA complex was measured using a spectrometer at a wavelength $(\lambda)$ of $532 \mathrm{~nm}$, while non-specific absorbance was measured at a wavelength $(\lambda)$ of $600 \mathrm{~nm}$ (Meriga et al. 2010). The MDA content is determined based on the equation from Heath and Packer (1968), as follows:

$\mathrm{MDA}=\frac{\left(\frac{\mathrm{A} 532-\mathrm{A} 600}{\varepsilon}\right) \times 10^{\wedge} 6}{\text { Fresh weight }(\mathrm{g})}$

MDA: MDA concentration ( $\mathrm{nmol} / \mathrm{g}$ )

$\varepsilon=$ MDA extention coefficient value $\left(155 \mathrm{mM}^{-1} \mathrm{~cm}^{-1}\right)$

Research design and data analysis. This study used a one-factor completely randomized design (CRD) with 5 levels of Al doses, namely 0, 2, 4, 6, and $8 \mathrm{mM}$. Each treatment was repeated 3 times and each replication consisted of 3 plant units. Data analysis used the Anova test followed by the Duncan Multiple's Range Test (DMRT) at a $95 \%$ confidence level $(\alpha=5)$.

\section{RESULTS AND DISCUSSION}

\section{Plant height}

The height growth of the two seedlings gave a significant difference at several Al concentrations (Figure 1). The $2 \mathrm{mM} \mathrm{Al}$ concentration provided the highest growth response in the two seedlings compared to other $\mathrm{Al}$ concentrations. Meanwhile, the increasing concentration of Al was able to reduce the height growth of the two seedlings. The height growth of $A$. chinensis was higher than that of $F$. moluccana.

\section{Root length}

The Al exposure treatment reduced the root length in $F$. moluccana seedlings until the concentration of $6 \mathrm{mM} \mathrm{Al}$. Meanwhile, in A. chinensis seedlings, the $2 \mathrm{mM} \mathrm{Al}$ concentration was able to increase root length and decrease again with increasing $\mathrm{Al}$ concentration (Figure 2). The $0 \mathrm{mM}$ and $2 \mathrm{mM} \mathrm{Al}$ concentrations did not show a significant difference, as did the $\mathrm{Al} \mathrm{4,6}$ and $6 \mathrm{mM}$ concentrations, nor did they significantly differ from the root length of $F$. moluccana seedlings. Meanwhile, in $A$. chinensis seedlings, the $2 \mathrm{mM}$ and $4 \mathrm{mM} \mathrm{Al}$ concentrations did not show any significant difference in root length. At these concentrations, it was the highest root length compared to other $\mathrm{Al}$ concentrations. 


\section{The dry weight}

Treatment of $2 \mathrm{mM} \mathrm{Al}$ concentration increased root, shoot and total dry weight in both seedlings (Figures 3, 4 and 5). However, the increasing concentration of $\mathrm{Al}$ was able to reduce dry weight in both seedlings. Root dry weight of $F$. moluccana and A. chinensis seedlings at concentrations of $0,4,6$, and $8 \mathrm{mM}$ did not show a significant difference (Figure 3). The shoot dry weight of $F$. moluccana seedlings showed no significant difference between the $\mathrm{Al} 0$ and 4

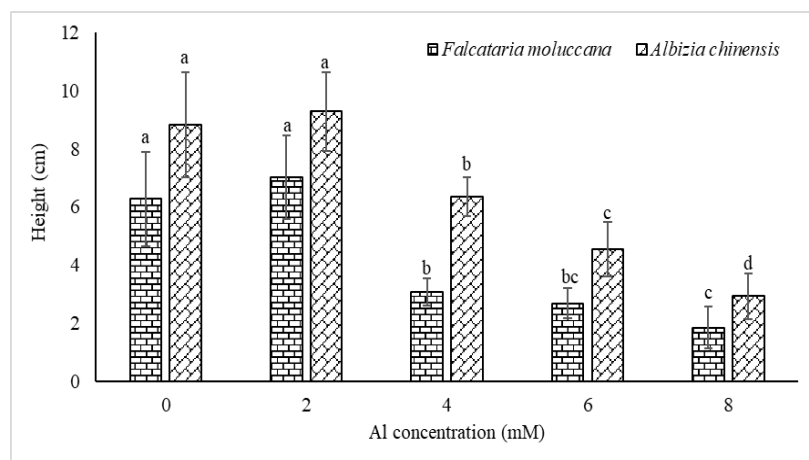

Figure 1. Height growth of $F$. moluccana and A. chinensis at various $\mathrm{Al}$ concentrations. Vertical bars indicate standard deviations $(n=3)$. Different letters show a sifnificant difference in the result of the DMRT test at the $5 \%$ level.

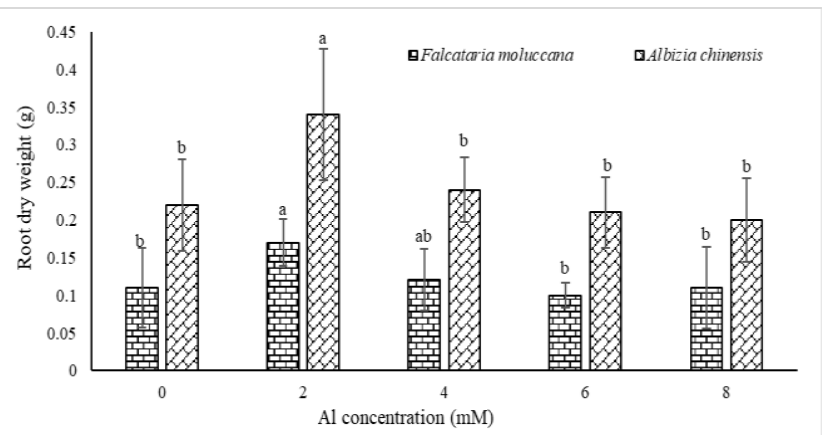

Figure 3. Roots dry weight of $F$. moluccana and A. chinensis at various $\mathrm{Al}$ concentrations. Vertical bars indicate standard deviations $(n=3)$. Different letters show a significant difference in the result of the DMRT test at the 5\% level.

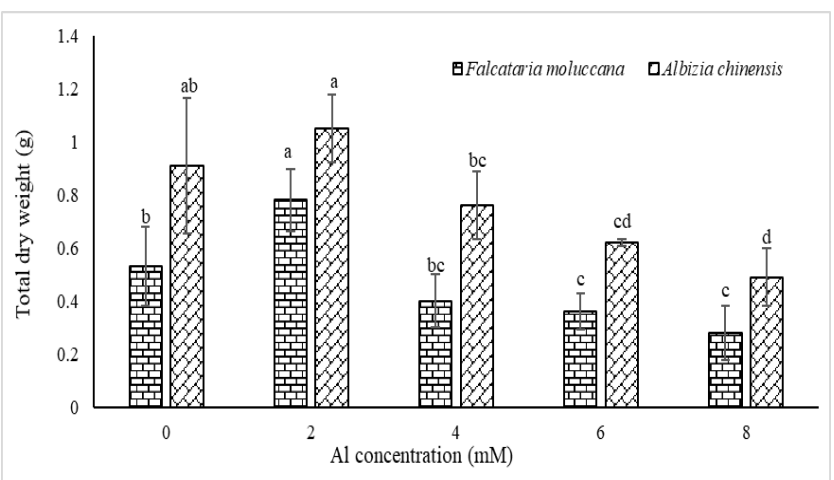

Figure 5. Total dry weight of $F$. moluccana and A. chinensis at various $\mathrm{Al}$ concentrations. Vertical bars indicate standard deviations $(\mathrm{n}=3)$. Different letters show a significant difference in the result of the DMRT test at the 5\% level.
$\mathrm{mM}$ concentrations and between the Al 6 and $8 \mathrm{mM}$ concentrations. Meanwhile, while, on the seedlings of $A$. chinensis $\mathrm{Al}$ exposure treatment provides significant differences between the concentrations of $\mathrm{Al}$, except between 6 and 8 $\mathrm{mM}$ concentration which showed no significant difference (Figure 4). The total dry weight of $A$. chinensis seedlings was higher than that of $F$. moluccana seedlings (Figure 5). It is shown that $A$. chinensis seedlings have higher growth compared to $F$. moluccana seedlings.

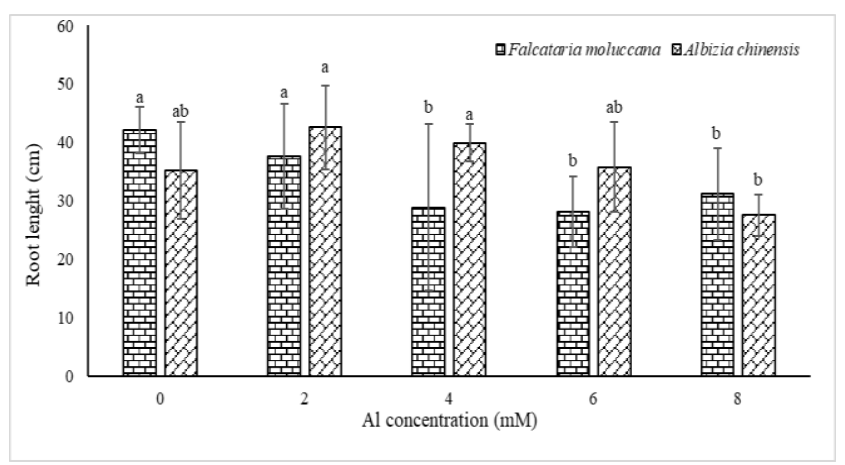

Figure 2. Root lengths of $F$. moluccana and A. chinensis at various $\mathrm{Al}$ concentrations. Vertical bars indicate standard deviations $(\mathrm{n}=3)$. Different letters show a significant difference in the result of the DMRT test at the 5\% level.

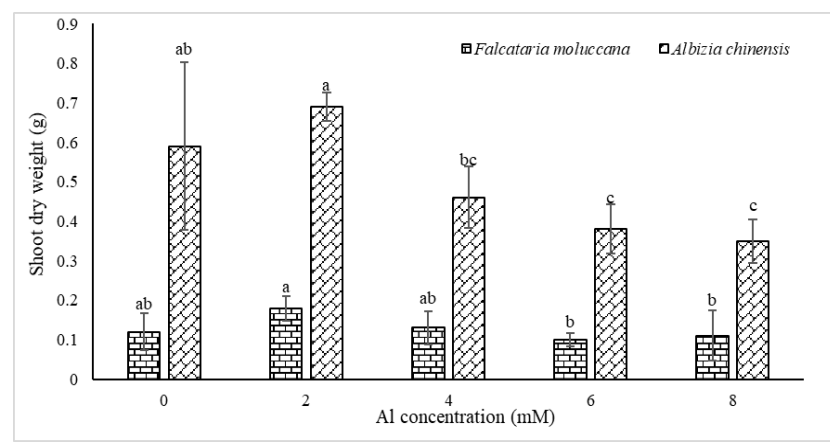

Figure 4. Shoots dry weight of $F$. moluccana and A. chinensis at various $\mathrm{Al}$ concentrations. Vertical bars indicate standard deviations $(n=3)$. Different letters show a significant difference in the result of the DMRT test at the 5\% level.

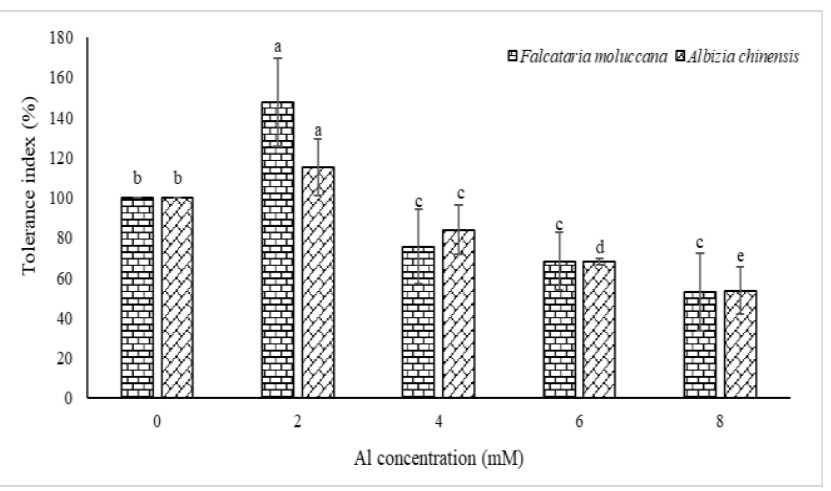

Figure 6. Tolerance index of $F$. moluccana and A. chinensis at various $\mathrm{Al}$ concentrations. Vertical bars indicate standard deviations $(n=3)$. Different letters show a significant difference in the result of the DMRT test at the 5\% level 
Table 1. Chlorophyll and carotenoid content of F. moluccana and A. chinensis at various $\mathrm{Al}$ concentrations

\begin{tabular}{|c|c|c|c|c|c|}
\hline \multirow{2}{*}{ Species } & \multicolumn{5}{|c|}{ Al concentration $(\mathrm{mM})$} \\
\hline & $\mathbf{0}$ & 2 & 4 & 6 & 8 \\
\hline \multicolumn{6}{|c|}{ Chlorophyll a (mg/g) } \\
\hline F. moluccana & $2.16 \pm 0.10 \mathrm{abc}$ & $2.29 \pm 0.09 \mathrm{a}$ & $1.93 \pm 0.07 \mathrm{c}$ & $2.23 \pm 0.26 \mathrm{ab}$ & $1.98 \pm 0.08 \mathrm{bc}$ \\
\hline A. chinensis & $3.22 \pm 0.14 \mathrm{a}$ & $3.29 \pm 0.36 \mathrm{a}$ & $2.52 \pm 0.27 \mathrm{~b}$ & $2.30 \pm 0.24 b$ & $1.75 \pm 0.26 \mathrm{c}$ \\
\hline \multicolumn{6}{|c|}{ Chlorophyll b (mg/g) } \\
\hline F. moluccana & $1.30 \pm 0.05 \mathrm{ab}$ & $1.42 \pm 0.03 \mathrm{a}$ & $1.20 \pm 0.03 b$ & $1.40 \pm 0.16 \mathrm{a}$ & $1.23 \pm 0.08 \mathrm{~b}$ \\
\hline A. chinensis & $1.98 \pm 0.14 \mathrm{a}$ & $2.04 \pm 0.18 \mathrm{a}$ & $1.58 \pm 0.16 b$ & $1.40 \pm 0.17 \mathrm{~b}$ & $1.09 \pm 0.15 \mathrm{c}$ \\
\hline \multicolumn{6}{|c|}{ Chlorophyll total (mg/g) } \\
\hline F. moluccana & $3.45 \pm 0.15 a b$ & $3.71 \pm 0.11 \mathrm{a}$ & $3.14 \pm 0.10 b$ & $3.63 \pm 0.42 \mathrm{a}$ & $3.20 \pm 0.14 b$ \\
\hline A. chinensis & $5.20 \pm 0.29 a$ & $5.33 \pm 0.53 a$ & $4.10 \pm 0.43 b$ & $3.70 \pm 0.41 \mathrm{~b}$ & $2.83 \pm 0.41 \mathrm{c}$ \\
\hline \multicolumn{6}{|c|}{ Carotenoids (mg/g) } \\
\hline F. moluccana & $0.71 \pm 0.04 \mathrm{ab}$ & $0.78 \pm 0.03 \mathrm{a}$ & $0.68 \pm 0.01 b$ & $0.79 \pm 0.08 \mathrm{a}$ & $0.71 \pm 0.03 \mathrm{ab}$ \\
\hline A. chinensis & $4.15 \pm 5.41 \mathrm{a}$ & $1.03 \pm 0.10 \mathrm{a}$ & $0.86 \pm 0.07 \mathrm{a}$ & $0.80 \pm 0.08 \mathrm{a}$ & $0.62 \pm 0.09 \mathrm{a}$ \\
\hline
\end{tabular}

Note: mean \pm standard deviation, the different letters show a significant difference in the DMRT test results at the 5\% level. *: significant effect at the 5\% level, ns: not significat at the 5\% level

\section{Tolerance index}

The $\mathrm{Al}$ exposure treatment gave a significant difference in the tolerance index for $F$. moluccana seedlings, while for A. chinensis seedlings only up to $4 \mathrm{mM} \mathrm{Al}$ concentration which resulted in a significant difference to the tolerance index (Figure 6). The tolerance index for F. moluccana and A. chinensis seedlings was the highest when the $\mathrm{Al} 2 \mathrm{mM}$ concentration exceeded the tolerance level of the seedlings under control treatment $(0 \mathrm{mM})$ with values of $147.55 \%$ and $115.32 \%$, respectively (Figure 6). However, the increasing concentration of $\mathrm{Al}$ (from $4 \mathrm{mM}$ to $8 \mathrm{mM}$ ) reduced the tolerance index in $F$. moluccana and $A$. chinensis.

\section{Chlorophyll and carotenoid content}

$2 \mathrm{mM} \mathrm{Al}$ exposure treatment increased the chlorophyll content a, b, total chlorophyll, and carotenoids of $F$. moluccana and A. chinensis seedlings (Table 1). The chlorophyll a, b, total chlorophyll, and carotenoid content of $F$. moluccana seedlings fluctuated considerably compared to A. chinensis seedlings. Meanwhile, the chlorophyll a, b, and total chlorophyll content of $A$. chinensis seedlings decreased when the $\mathrm{Al}$ concentration was 4 to $8 \mathrm{mM}$. It is shown that the higher $\mathrm{Al}$ concentration can reduce the chlorophyll content of $A$. Chinensis seedlings. The carotenoid content of $A$. chinensis seedlings decreased with increasing $\mathrm{Al}$ concentration.

\section{Photosynthesis rate}

Al exposure treatment did not significantly differ in the rate of photosynthesis in $F$. moluccana and A. chinensis seedlings (Figure 7). The photosynthesis rate in the two seedlings was quite fluctuating. The highest photosynthetic rate of $F$. moluccana seedlings was when the $\mathrm{Al}$ concentration was $2 \mathrm{mM}(18.39 \mu \mathrm{mol} \mathrm{CO} 2 \mathrm{~m}-2 \mathrm{~s}-1)$, while in $A$. chinensis seedlings, the highest photosynthetic rate was when the $\mathrm{Al}$ concentration was $4 \mathrm{mM}(15.36 \mu \mathrm{mol}$ $\mathrm{CO} 2 \mathrm{~m}-2 \mathrm{~s}-1)$. It is indicated that the two seedlings responded quite differently to $\mathrm{Al}$ exposure to the rate of photosynthesis.

\section{MDA content}

Lipid peroxidation (malondialdehyde) is a response from plants due to exposure to heavy metals. Al exposure did not show a significant difference in the MDA content of the two species of seedlings (Figure 8). The MDA content of both species of seedlings at various concentrations of $\mathrm{Al}$ was quite varied, and the MDA content of $F$. moluccana seedlings was higher than that of $A$. chinensis seedlings. The highest MDA content in both seedlings was at a concentration of $4 \mathrm{mM}$, and this indicates that with an $\mathrm{Al}$ concentration of $4 \mathrm{mM}$, it was able to trigger MDA production.

\section{Al content in seedling tissue}

Al content in the tissue (roots and shoots). seedling $F$. moluccana and $A$. chinensis were able to increase when the concentration of $\mathrm{Al}$ also increases (Table 2). The Al content in the roots was higher than in the shoots of the two seedlings. It is shown that the $\mathrm{Al}$ uptake is more accumulated in the roots than in the shoots.

Table 2. The content of $\mathrm{Al} \mathrm{F.} \mathrm{moluccana} \mathrm{and} \mathrm{A.} \mathrm{chinensis} \mathrm{in} \mathrm{roots}$ and shoots at various concentrations of $\mathrm{Al}$

\begin{tabular}{lccccc}
\hline \multirow{2}{*}{ Species } & \multicolumn{5}{c}{ Al concentration (mM) } \\
\cline { 2 - 6 } & $\mathbf{0}$ & $\mathbf{2}$ & $\mathbf{4}$ & $\mathbf{6}$ & $\mathbf{8}$ \\
\hline Al content in roots (ppm) & & & & \\
F. moluccana & - & 12.045 & 12.423 & 14.4 & 14.748 \\
A. chinensis & - & 7.675 & 14.366 & 15.376 & 15.751 \\
Al content in shoots (ppm) & & & \\
$\quad$ F. moluccana & - & 0.408 & 1.304 & 1.511 & 2.18 \\
A. chinensis & - & 0.442 & 0.839 & 2.292 & 3.15 \\
\hline
\end{tabular}




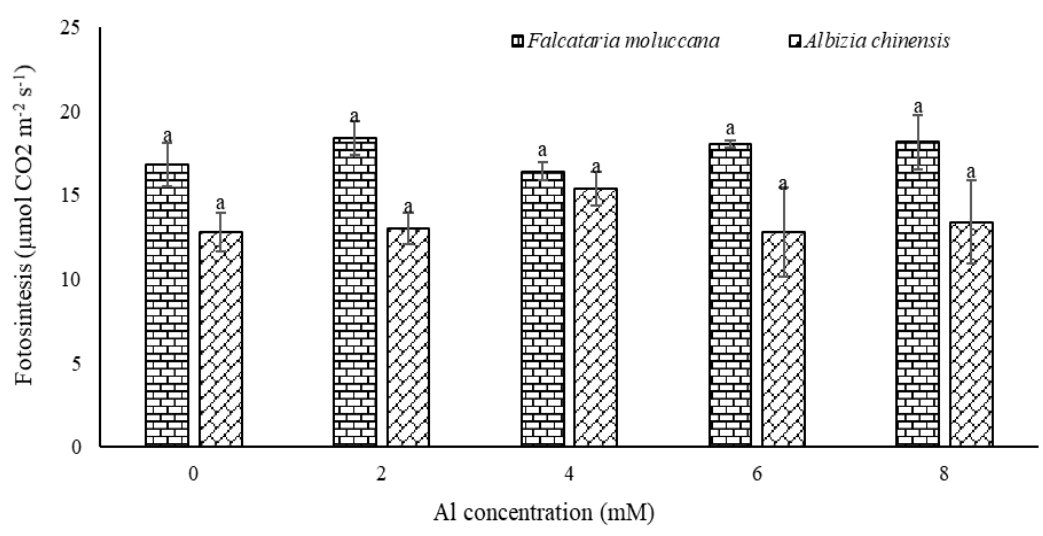

Figure 7. Photosynthetic rate of F. moluccana and A. chinensis at various Al concentrations. Vertical bars indicate standard deviations $(\mathrm{n}=3)$. Different letters show a significant difference in the result of the DMRT test at the $5 \%$ level

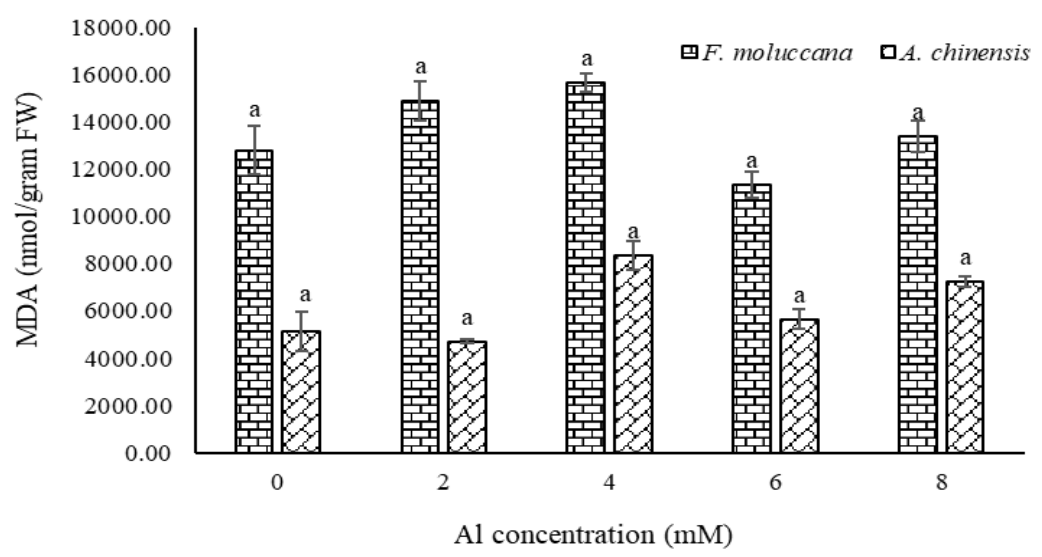

Figure 8. MDA content of $F$. moluccana and A. chinensis at various $\mathrm{Al}$ concentrations. Vertical bars indicate standard deviations (n = 3). Different letters show a significant difference in the result of the DMRT test at the $5 \%$ level.

\section{Discussion}

$\mathrm{Al}$ is a non-essential metal. Its function is not widely known in plant metabolism (Wang and Kao 2004). Each plant can respond to $\mathrm{Al}$ toxicity differently (Arunakumara et al. 2013). Al exposure can reduce growth in several plant species that are sensitive to $\mathrm{Al}$ (Böhlenius et al. 2018). However, at specific concentrations, $\mathrm{Al}$ can stimulate plant growth (Arunakumara et al. 2013). It was proven that 2 $\mathrm{mM}$ Al concentration was able to stimulate the height growth of $F$. moluccana and $A$. chinensis seedlings (Figure 1). However, when the $\mathrm{Al}$ concentration increased (4 to 8 $\mathrm{mM})$, it reduced the height growth of the two seedlings. Pidjath et al. (2020) reported that $\mathrm{Al}$ concentration of 4 $\mathrm{mM}$ was able to inhibit growth and nutrient uptake of four forest seedlings (C. calothyrsus, S. saman, O. bicolor, and C. inophyllum). Singh et al. (2011) also reported that $\mathrm{Al}$ toxicity was able to reduce the growth of $P$. sativam $\mathrm{L}$. Arkil and Rachana varieties. Böhlenius et al. (2018) reported that $200-300 \mathrm{mg} / \mathrm{l} \mathrm{Al}$ exposure treatment reduces the relative height growth, root, leaf, and stem biomass relative to four poplar cultivars.
High concentrations of $\mathrm{Al}$ can inhibit root growth and development (Motoda et al. 2010; Kopittke et al. 2015). The results of this study also showed that increasing $\mathrm{Al}$ concentration was able to reduce the root length of $F$. moluccana and A. chinensis seedlings (Figure 2). Tolra et al. (2009) reported that Al toxicity did not improve the root length of the Cateto variety Zea mays L. (tolerant). Gunsé et al. (2003) also reported that Al toxicity had little inhibition on root exposure of $P$. vulgaris $\mathrm{L}$. Preto and Carioca varieties (tolerant) and Andean varieties (tolerant). Meanwhile, several studies reported that Al toxicity was able to inhibit root lengthening of soybean varieties Zhechun 2 (tolerant) and Huachun 18 (sensitive) (Cai et al. 2011), Phaseolus vulgaris L. Quimbaya varieties (tolerant) and VAX-1 varieties (sensitive) (Rangel et al. 2009). Al in low concentration $(2 \mathrm{mM})$ was able to stimulate the root length of the $F$. moluccana plant. This condition is probably caused by an increase in the apical root meristem activity induced by $\mathrm{Al}$ (Arunakumara et al. 2013). Yu et al. (2011) reported that $\mathrm{Al}$ of low concentrations $(10-30 \mathrm{mg} / \mathrm{L})$ was able to increase root activity, maintain a reasonably 
high root respiratory metabolism, and increase the ability to absorb water and nutrients. Restoration of plant root length is highly dependent on the ability to withstand oxidative stress and reduce lignin production (Matsumoto and Matoda 2012). The immobilization of Al-pectin at the root cell border has played an important role in protecting the root apex from exposure to $\mathrm{Al}$ (Yu et al. 2009). Inhibition of root length was due to the binding of $\mathrm{Al}$ in the root cell walls (Rangel et al. 2009). The root tip or root apex is the most sensitive area to Al toxicity (Huang et al. 2009). Roots affected by Al toxicity have an impact on water and nutrient absorption inhibition (Sun et al. 2010; Abate et al. 2013; Kichigina et al. 2017), thereby reducing plant growth (Wang et al. 2006; Miyasaka et al. 2007). The results of several studies reported that $\mathrm{Al}$ toxicity was able to damage the cell ultrastructure of longan (Xiao et al. 2003) and wheat (Li et al. 2006). Al concentrations in several micromolar (5 - >5 micromolar) can inhibit plant root growth quickly (Matsumoto and Motoda 2012; Pattanayak and Pfukrei 2013). Yu et al. (2011) reported that increasing the $\mathrm{Al}$ concentration was able to reduce the total root volume of soybean cultivars Z.2 and Z.3.

Biomass and height are among the agronomic parameters that correlate with plant tolerance to $\mathrm{Al}$ exposure (Anas and Yoshida 2004). Al toxicity can reduce plant biomass (Abate et al. 2013). However, at certain concentrations, Al can increase plant biomass. This study also showed that $2 \mathrm{mM} \mathrm{Al}$ concentration was able to stimulate root, shoot and total dry weight of $F$. moluccana and A. chinensis seedlings (Figures 3, 4, 5). Meanwhile, increasing the $\mathrm{Al}$ concentration (2 to $4 \mathrm{mM}$ ) reduced the dry weight of roots, shoots, and the total in both seedlings. It is because the growth in height and root length of the two seedlings began to decrease when the $\mathrm{Al}$ concentration was $2 \mathrm{mM}$ to $8 \mathrm{mM}$. These conditions have an impact on reducing root, shoot, and total dry weight in both seedlings. Kichigina et al. (2017) reported that Al 80 $\mathrm{ml} \mathrm{AlCl}{ }_{3}$ treatment for 10 was able to decrease root and shoot biomass in soybean genotypes.

Increasing the $\mathrm{Al}$ concentration ( 4 to $8 \mathrm{mM}$ ) reduced the tolerance index level of the two species of plants (Figure 6). It is shown that $\mathrm{Al}$ is capable of being toxic when available in high concentrations $(8 \mathrm{mM})$. Each plant can develop various mechanisms to tolerate $\mathrm{Al}$ exposure (Garzon et al. 2011; Pattanayk and Pfukrei 2013). Exclusion and detoxification of $\mathrm{Al}$ in roots is a common mechanism for plants to tolerate Al toxicity (Kochian et al. 2004; Abate et al. 2013). In addition, plants also develop an organic acid exudation mechanism to tolerate $\mathrm{Al}$ exposure (Singh and Chaucan 2011; Abate et al. 2013; Kichigina et al. 2017). Organic acids can chelate $\mathrm{Al}$ so that $\mathrm{Al}$ does not become toxic to plants (Ryan et al. 2011). Organic acids such as malic, oxalate, and citric have been positively correlated with plant tolerance to Al toxicity (Mimmo et al. 2013; Vondráčková et al. 2015). The results of several studies reported that exudation of citric, oxalic and malic acids in $P$. tremuloides and $P$. trichocarpa (Naik et al. 2009) and P. tremula (Qin et al. 2007).

The content of chlorophyll and carotenoids in $F$. moluccana seedlings was more fluid, while in $A$. chinensis seedlings the increase in $\mathrm{Al}$ concentration reduced the chlorophyll and carotenoid content (Table 1). This condition indicates that $F$. moluccana seedlings can adapt well to several $\mathrm{Al}$ concentrations to a certain extent. Al toxicity can reduce chlorophyll content (Abdalla 2008; Mukhopadyay et al. 2012). The decrease in chlorophyll content is related to disruption of $\mathrm{Mg}$ uptake and transportation because $\mathrm{Mg}$ is an integral part of the chlorophyll molecule (Ali 2008). Al exposure was able to reduce the chlorophyll content and the photosynthetic rate of eucalyptus plants, where the $\mathrm{Al} 4.4 \mathrm{mM}$ concentration with a pH of 3 significantly reduced these two parameters (Yang et al. 2015). Guo et al. (2012) reported that AL toxicity was able to reduce the chlorophyll content of Oryza sativa L. cultivars Xiushui 132 (tolerant) and Yongyou 8 (sensitive).

The rates of photosynthesis in $F$. moluccana and $A$. chinensis seedlings did not show significant difference between $\mathrm{Al}$ concentrations (Figure 7). The decrease in the rate of photosynthesis is one of the effects of Al toxicity (Abate et al. 2013). ROS accumulation causes oxidative stress and results in damage to the photosynthetic process equipment (Yang et al. 2015). In addition, the decrease in the rate of photosynthesis is caused by the $\mathrm{Al}$ stress can inhibit the process of nutrient absorption and cause plants to become deficient (Ridolfi and Garrec 2000). Martins et al. (2013) reported that aluminum was able to significantly reduce photosynthetic pigments in Plantago algarbiensi with soil $\mathrm{pH} 4.0$.

Lipid peroxides exhibit oxidative damage to lipids containing several carbon-carbon double bonds (Jin et al. 2008). Lipid peroxide in plants is caused by toxicity from heavy metal exposure (Washa et al. 2012). The increase in MDA levels indicates that heavy metals cause oxidative stress in plants. The presence of heavy metal treatment can stimulate the production of MDA, which is thought to be the result of the formation of free radicals (Panda et al. 2003). This can be seen in the results of the study, where at some $\mathrm{Al}$ concentrations the MDA content of both seedlings increased, although it did not show a significant difference between $\mathrm{Al}$ concentrations (Figure 8). The highest MDA content in both seedlings was when the $\mathrm{Al}$ concentration was $4 \mathrm{mM}$. This indicated that the $\mathrm{Al}$ concentration of 4 $\mathrm{mM}$ was able to cause oxidative stress in both seedlings. However, the MDA content in both seedlings decreased again when the $\mathrm{Al}$ concentrations were 6 and $8 \mathrm{mM}$. This finding is different from results reported by Jin et al. (2008) that the higher concentration of the metal can increase the levels of MDA in plants.

Al toxicity is also capable of causing oxidative stress caused by the increase and accumulation of ROS (Darkó et al. 2004). This condition disrupts plant metabolism (Inostroza-Blancheuteau et al. 2012; Yamamoto et al. 2002), causes damage to DNA (Meriga et al. 2010), cell homeostasis, DNA strand or band damage, protein defragmentation, cell membrane damage, and photosynthetic pigments, and stimulates plant cell damage (Flora 2009; Miller et al. 2010; Rout and Sahoo 2015). Increased production of ROS such as superoxide free radicals $\left(\mathrm{O}^{-}{ }^{-}\right)$, hydroxyl free radicals $\left(\mathrm{OH}^{-}\right)$, singlet oxygen 
$(\mathrm{O} 2 *)$, and hydrogen peroxide $\left(\mathrm{H}_{2} \mathrm{O}_{2}\right)$ as cytotoxic compounds that can cause disruptive oxidative stress. The balance between pre-oxidants and homeostasis in plant cells (Hossain et al. 2012). The accumulation of ROS can produce lipid peroxides, which in turn can damage the biofunctions of cell members and plant cell metabolism, which will reduce plant growth (Sytar et al. 2013; Mathimaran et al. 2017).

The $\mathrm{Al}$ concentration or total $\mathrm{Al}$ content in plant tissue is strongly influenced by the treatment given, the plant organs analyzed, and the Al concentration in the soil (Vondráčková et al. 2015). The results showed that the $\mathrm{Al}$ content in $F$. moluccana and A. chinensis seedlings was higher in the roots than in the shoots in each treatment. The Al content of $F$. moluccana and A. chinensis seedling tissue increased when the concentration of $\mathrm{Al}$ was available in high concentrations $(6-8 \mathrm{mM})$. The difference in $\mathrm{Al}$ distribution between the two seedlings can be presumed due to the different $\mathrm{Al}$ detoxification mechanisms in each plant (Vondráčková et al. 2015). Teraoka et al. (2002) reported that $\mathrm{Al}$ accumulation was higher in roots of Triticum aestivum L. Brevor variety. Al accumulation in eucalyptus roots is strongly influenced by soil $\mathrm{pH}$ (Godbold and Brunner 2007). However, several studies have reported that $\mathrm{Al}$ tolerance is not correlated with $\mathrm{Al}$ content in roots (Bernal and Clark 1997; Kichigina et al. 2017).

Al exposure treatment gave significant differences in the growth of height, root length, dry weight (root, shoot, and total) of $F$. moluccana and $A$. chinensis seedlings. Low $\mathrm{Al}$ concentration $(2 \mathrm{mM})$ was able to trigger the growth of A. chinensis seedlings. The tolerance index of the two seedlings was highest when the Al concentration was 2 $\mathrm{mM}$, which indicated that both species of seedlings were able to grow well with exposure to $\mathrm{Al}(2 \mathrm{mM})$. Al content in seedling tissue of $F$. moluccana and A. chinensis increased when $\mathrm{Al}$ concentration was high (6-8 $\mathrm{mM})$. These results can be used as the basis that $F$. moluccana and A. chinensis species can be used as plants for revegetation activities on lands that have low $\mathrm{Al}$ content.

\section{ACKNOWLEDGEMENTS}

This research was funded by the Deputy for Strengthening Research and Development of the Ministry of Research and Technology Research and Innovation Agency following the 2020 Research Implementation Agreement Number: 1/E1/KP.PTNBH/2020 and Number: 1/AMD/E1.KP.PTNBH/2020 and Number: 1/E1/KP.PTNBH/2021 with the PMDSU (Program Magister Menuju Doktor untuk Sarjana Unggul) program Research scheme.

\section{REFERENCES}

Abate E, Hussien S, Laing M, Mengistu F. 2013. Aluminum toxicity tolerance in cereals: mechanisms, genetic control and breeding methods. Afr J Agric 8 (9): 711-722. DOI: 10.5897/AJARx12.003.
Abdalla MM. 2008. Physiological aspects of aluminium toxicity on some metabolic and hormonal contents of Hordeum vulgare seedlings. Aust J Basic App Sci 2: 549-560.

Aiso H, Ishiguri F, Toyoizumi T, Ohshima J, Iizuka K, Priadi D, Yokota S. 2016. Anatomical, chemical, and physical characteristics of tension wood in two tropical fast-growing species, Falcataria moluccana and Acacia auriculiformis. Tropics 25 (1): 33-41. DOI: 10.3759/tropics.25.33

Alghofar WA, Purnamaningsih SL, Damanhuri. 2007. Effect temperature and soaked time on germination and seedling growth sengon (Paraserianthes falcataria L. Nielsen). Jurnal Produksi Tanaman 5 (10): 16391644. [Indonesian]

Ali B, Hasah SA, Hayat S, Hayat Y, Yadav S, Fariduddin Q, Ahmad A. 2008. A role for brassinosteroids in the amelioration of aluminium stress through antioxidant system in mung bean (Vigna radiata L. Wilczek). Environ Exp Bot 62 (2): 153-159. DOI: 10.1016/j.envexpbot.2007.07.014.

Anas A, Yoshida T. 2004. Heritability and genetic correlation of Altolerance with several agronomic characters in sorghum assessed by hematoxylin staining. Plant Prod Sci 7 (3): 280-282. DOI: $10.1626 /$ pps.7.280

Arunakumara KKIU, Walpola BC, Yoon M-H. 2013. Aluminum toxicity and tolerance mechanism in cereals and legumes-a review. J Korean Soc Appl Biol Chem 56 (1): 1-9. DOI: 10.1007/s13765-012-2314-z.

Balsberg Pahlsson AM. 1990. Influence of aluminumon biomass, nutrients, soluble carbohydrate and phenolsin beech (Fagus sylvatica). Physiol Plant 78 (1): 79-84. DOI: 10.1111/j.13993054.1990.tb08718.x.

Bernal JH, Clark RB. 1997. Mineral acquisition of aluminum-tolerant and sensitive sorghum genotypes grown with varied aluminum. Commun Soil Sci Plant Anal 28 (1-2): 49-62. DOI: 10.1080/00103629709369771.

Böhlenius H, Asp H, Hjelm. 2018. Differences in Al sensitivity affect establishment of Populus genotypes on acidic forest land. PloS ONE 13 (9): e0204461. DOI: 10.1371/journal.pone.0204461.

Cai MZ, Wang FM, Li RF, Zhang SN, Wang N, Xu GD. 2011. Response and tolerance of root border cells to aluminum toxicity in soybean seedlings. J Inorg Biochem 105 (7): 966-971. DOI: 10.1016/j.jinorgbio.2011.04.004.

Flora SJS. 2009. Structural, chemical and biological aspects of antioxidants for strategies against metal and metalloid exposure. Oxid Med Cell Long 2 (4): 191-206. DOI: 10.4161/oxim.2.4.9112.

Garzon T, Gunse B, Moreno AR, Tomos AD, Barcelo J, Poschenrieder C. 2011. Aluminium-induced alteration of ion homeostasis in root tip vacuoles of two maize varieties differing in Al tolerance. Plant Sci 180 (5): 709-15. DOI: 10.1016/j.plantsci.2011.01.022.

Godbold DL, Brunner I. 2007. The platform for European root science, COST action E38: an introduction and overview. Plant Biosyst 141 (3): 390-403. DOI: 10.1080/11263500701625715.

Gunsé B, Garzón T, Barceló J. 2003. Study of aluminum toxicity by means of vital staining profiles in four cultivars of Phaseolus vulgaris L. J Plant Physiol 160 (12): 1447-50. DOI: 10.1078/0176-1617-01001

Guo TR, Yao PC, Zhang ZD, Wang JJ, Wang M. 2012. Devolvement of antioxidative defense system in rice-growing seedlings exposed to Aluminum toxicity and Phosphorus deficiency. Rice Sci 19 (3): 17985. DOI: 10.1016/S1672-6308(12)60042-0.

Heath RL, Packer L. 1968. Photoperoxidation in isolated chloroplasts: I. Kinetics and stoichiometry of fatty acid peroxidation. Arch Biochem Biophysics 125 (1): 189-198. DOI: 10.1016/0003-9861(68)90654-1.

Hossain MA, Piyatida P, da Silva JAT, Fujita M. 2012. Molecular mechanism of heavy metal toxicity and tolerance in plants: central role of glutathione in detoxification of reactive oxygen species and methylglyoxal and in heavy metal chelation. J Bot. DOI: $10.1155 / 2012 / 872875$.

Huang J, Xia HP, Li Z, Xiong YM, Kong GH, Huang J. 2009. Soil aluminium uptake and accumulation by Paspalum notatum. Waste Manag Res 27 (7): 668-675. DOI: 10.1177/0734242X09103835.

Hughes RF, Uowolo A. 2006. Impacts of Falcataria moluccana invasion on decomposition in Hawaiian lowland wet forests: the importance of stand-level controls. Ecosystems 9 (6): 977-991. DOI: 10.1007/s10021-005-0083-9.

Hughes RF, Uowolo AL, Togia TP. 2012. Recovery of native forest after removal of an invasive tree, Falcataria moluccana, in American Samoa. Biol Invasions 14 (7): 1393-1413. DOI: 10.1007/s10530-0110164-y. 
Inostroza-Blancheteau C, Rengel Z, Alberdi M, de la Luz Mora M, Aquea F, Arce-Johnson P, Reyes-Díaz M. 2012. Molecular and physiological strategies to increase aluminum resistance in plants. Mol Biol Rep 39 (3): 2069-2079. DOI: 10.1007/s11033-011-0954-4.

Jin X, Yang X, Islam E, Liu D, Mahmood Q. 2008. Effects of cadmium on ultrastructure and antioxidative defense system in hyperaccumulator and non-hyperaccumulator ecotypes of Sedum alfredii Hance. J Hazard Mater 156 (1-3): 387-397. DOI: 10.1016/j.jhazmat.2007.12.064

Kichigina NE, Puhalsky JV, Shaposhnikov AI, Azarova TS, Makarova NM, Loskutov SI, Safronova VI, Tikhonovich IA, Vishnyakova MA, Semenova EV, et al. 2017. Aluminum exclusion from root zone and maintenance of nutrient uptake are principal mechanisms of $\mathrm{Al}$ tolerance in Pisum sativum L. Physiol Mol Biol Plants 23: 851-863.

Kochian LV, Hoekenga OA, Piñeros MA. 2004. How do crop plant tolerate acid soils? mechanisms of aluminum tolerance and phosphorous efficiency. Annu Rev Plant Biol 55: 459-493. DOI: 10.1146/annurev.arplant.55.031903.141655.

Konarska A. 2008. Changes in the ultrastructure of Capsicum annuum L. seedlings roots under aluminum stress conditions. Acta Agrobot 61: 27-32.

Kopittke PM, Moore KL, Gianoncelli A, Ferguson BJ, Blamey PC, Menzies NW, Nicholson TM, McKenna BA, Wang P, Gresshoff PM, Kourousias G, Webb RI, Green K, Tollenaere A. 2015. Identification of the primary lesion of toxic aluminum in plant roots. Plant Physiol 167 (4): 1402-1411. DOI: 10.1104/pp.114.253229.

Li CS, Liu P, Xu GD, Lin HJ. 2006. Ameliorating effects of exogenous organic acids on aluminum toxicity in buckwheat seedlings. J Acta Agron Sin 32: 532-539

Lilienfein J, Qualls RG, Uselman SM, Bridgham SD. 2003. Soil formation and organic matter accretion in a young andesitic chronosequence at Mt. Shasta, California. Geoderma 116 (3-4): 249-64. DOI: 10.1016/S0016-7061(03)00086-7.

Liu YJ, Ding H. 2008. Variation in air pollution tolerance index of plants near a steel factory: Implications for landscape-plant species selection for industrial areas. WSEAS Trans Environ Dev 4 (1): 24-32.

Liu J, Piñeros MA, Kochian LV. 2014. The role of aluminium sensing and signaling in plant aluminum resistance. J Integr Plant Biol 56 (3): 221-230. DOI: 10.1111/jipb.12162.

Mathimaran N, Sharman MP, Mohan RJ, Bagyaraj DJ. 2017. Arbuscular mycorrhizal symbiosis and drought tolerance in crop plants. Mycosphere 8 (3): 361-376. DOI: 10.5943/mycosphere/8/3/2.

Martins N, Osório ML, Gonçalves S, Osório J, Palma T, Romano A. 2013. Physiological responses of Plantago algarbiensis and $P$ almogravensis shoots and plantlets to low $\mathrm{pH}$ and aluminum stress. Acta Physiol Plant 35 (2): 615-625. DOI: 10.1007/s11738-012-1102-z

Matsumoto H, Motoda H. 2012. Aluminum toxicity recovery processes in root apices; possible association with oxidative stress. Plant Sci 186: 1-8. DOI: 10.1016/j.plantsci.2011.07.019

Meriga B, Attitalla IH, Ramgopal M, Ediga A, Kavikishor PB. 2010. Differential tolerance to Aluminum toxicity in rice cultivars: Involvement of antioxidative enzymes and possible role of Aluminum resistant locus. Acad J Plant Sci 3 (2): 53-63.

Miller G, Suzuki N, Ciftci-Yilmaz S, Mittler R. 2010. Reactive oxygen species homeostasis and signaling during drought and salinity stresses. Plant Cell Environ 33 (4): 453-467. DOI: 10.1111/j.13653040.2009.02041.x

Mimmo T, Ghizzi M, Cesco S, Tomasi N, Pinton R, Puschenreiter M 2013. Aluminium-phosphate interactions in the rhizosphere of two bean species: Phaseolus lunatus L. and Phaseolus vulgaris L. J Sci Food Agric 93 (15): 3891-3896. DOI: 10.1002/jsfa.6392.

Miyasaka SC, Hue NV, Dunn MA. 2007. Aluminum. In: Barker AV, Pilbeam DJ (eds) Handbook of Plant Nutrition Tayler and Francis Group, Boca Raton.

Motoda H, Kano Y, Hiragami F, Kawamura K, Matsumoto H. 2010 Morphological changes in the apex of pea roots during and after recovery from aluminum treatment. Plant Soil 333 (1): 49-58. DOI: 10.1007/s11104-010-0318-1.

Mukhopadyay M, Bantawa P, Das A, Sarkar B, Bera B, Ghosh P, Mondal TK. 2012. Changes of growth, photosynthesis and alteration of leaf antioxidative defence system of tea [Camellia sinensis (L.) O. Kuntze] seedlings under aluminum stress. Biometals 25: 1141-1154.

Naik D, Smith E, Cumming JR. 2009. Rhizosphere carbon deposition, oxidative stress and nutritional changes in two poplar species exposed to aluminum. Tree Physiol 29 (3): 423-436. DOI: 10.1093/treephys/tpn035
Nunes-Nesi A, Brito DS, Inostroza-Blancheteau C, Fernie AR, Araújo WL. 2014. The complex role of mitochondrial metabolism in plant aluminum resistance. Trends Plant Sci 19 (6): 399-407. DOI: 10.1016/j.tplants.2013.12.006

Panda SK, Chaudhury I, Khan MH. 2003. Heavy metals induced lipid peroxidation and affect antioxidants in wheat leaves. Biol Plant 46 (2): 289-294. DOI: 10.1023/A:1022871131698.

Panda SK, Baluska F, Matsumoto H. 2009. Aluminum stress signaling in plants. Plant Signal Behav 4 (7): 592-597. DOI: 10.4161/psb.4.7.8903

Pattanayak A, Pfukrei K. 2013. Aluminium toxicity tolerance in crop plants: Present status of research. Afr J Biotech 12 (24): 3752-3757. DOI: $10.5897 / \mathrm{AJB} 12.2524$.

Pidjath C, Sopandie D, Turjaman M, Budi SW. 2021. Morphophysiological changes of four tropical tree seedlings under aluminum $\begin{array}{llll}\text { stress. Biodiversitas } 22 & \text { (3): } 1210-1220 . & \text { DOI: }\end{array}$ 10.13057/biodiv/d220317.

Prematuri R, Turjaman M, Sato T, Tawaraya K. 2020. Post bauxite mining land soil characteristics and its effects on the growth of Falcataria moluccana (Miq.) Barneby \& J. W. Grimes and Albizia saman (Jacq.) Merr. App Environ Soil Sci 8. DOI: $10.1155 / 2020 / 6764380$.

Qin R, Hirano Y, Brunner I. 2007. Exudation of organic acid anions from poplar roots after exposure to $\mathrm{Al}, \mathrm{Cu}$ and $\mathrm{Zn}$. Tree Physiol 27 (2): 313-320. DOI: 10.1093/treephys/27.2.313.

Rangel AF, Rao IM, Horst WJ. 2009. Intracellular distribution and binding state of aluminum in root apices of two common bean (Phaseolus vulgaris) genotypes in relation to $\mathrm{Al}$ toxicity. Physiol Plant 135 (2): 162-173. DOI: 10.1111/j.1399-3054.2008.01183.x.

Ridolfi M, Garrec JP. 2000. Consequences of an excess Al and a deficiency in $\mathrm{Ca}$ and $\mathrm{Mg}$ for stomatal functioning and net carbon assimilation of beech leaves. Ann Forest Sci 57 (3): 209-218. DOI: 10.1051/forest:2000112.

Rout GR, Sahoo S. 2015. Role of iron in plant growth and metabolism. Rev Agric Sci 3: 1-24. DOI: 10.7831/ras.3.1.

Ryan PR, Tyerman SD, Sasaki T, Furuichi T, Yamamoto Y, Zhang WH, Delheize E. 2011. The identification of aluminium-resistance genes provides opportunities for enhancing crop production on acid soils. J Exp Bot 62 (1): 9-20. DOI: 10.1093/jxb/erq272.

Sarimah S, Karyati, Karmini, Simbolon J, Tambunan E. 2018. Rehabilitation and soil conservation of degraded land using sengon (Falcataria moluccana) and peanut (Arachis hypogaea) agroforestry system. Biodiversitas 19: 222-228. DOI: 10.13057/biodiv/d190130.

Schmitt M, Watanabe T, Jansen S. 2016. The effects of aluminium on plant growth in a temperate and deciduous aluminium accumulating species. AoB Plants 8: 1-13. DOI: 10.1093/aobpla/plw065

Silva S. 2012. Aluminum toxicity targets in plants. J Bot 2012: 219-62. DOI: $10.1155 / 2012 / 219462$

Sims DA, Gamon JA. 2002. Relationships between leaf pigment content and spectral reflectance across a wide range of species, leaf structures and developmental stages. Remot Sens Environ 81 (2-3): 337-354. DOI: 10.1016/S0034-4257(02)00010-X

Singh NB, Yadav K, Amist N. 2011. Phytotoxic effects of Aluminum on growth and metabolism of Pisum sativum L. Intl J Innov Biol Chem Sci 2: 10-21.

Singh D, Chauhan SK. 2011. Organic acids of crop plants in aluminium detoxification. Curr Sci 100: 1509-1515.

Singh S, Tripathi DK, Singh S, Sharma S, Dubey NK, Chauhan DK, Vaculík. 2017. Toxicity of aluminium on various levels of plant cells and organism: a review. Environ Exp Bot 137: 177-193. DOI: 10.1016/j.envexpbot.2017.01.005

Siska DM, Hamim, Miftahudin. 2017. Overexpression of B11 gene in transgenic rice increased tolerance to aluminum stress. HAYATI J Biosci 24 (2): 96-104. DOI: 10.1016/j.hjb.2017.08.003

Sopandie D. 1999. Genotypic differential of aluminum tolerance in soybean related to organic acid exudation and nitrate metabolism. Comm Agric 5 (1): 13-20.

Sun P, Tian QY, Chen J, Zhang WH. 2010. Aluminum-induced inhibition of root elongation in Arabidopsis is mediated by Ethylene and Auxin. J Exp Bot 61 (2): 346-56. DOI: 10.1093/jxb/erp306

Sytar O, Kumar A, Latowski D, Kuczynska P, Strzałka K, Prasad MNV. 2013 Heavymetal-induced oxidative damage, defense reactions, and detoxification mechanisms in plants. Acta Physiol Plant 35 (4): 985999. DOI: 10.1007/s11738-012-1169-6

Teraoka T, Kaneko M, Mori S, Yoshimura E. 2002. Aluminum rapidly inhibits cellulose synthesis in roots of barley and wheat seedlings. J Plant Physiol 159 (1): 17-23. DOI: 10.1078/0176-1617-00678 
Tolra R, Barcelo J, Poschenrieder C. 2009. Constitutive and aluminium induced patterns of phenolic compounds in two maize varieties differing in aluminium tolerance. J Inorg Biochem 103 (11): 1486-90. DOI: 10.1016/j.jinorgbio.2009.06.013

Uddin MB, Khan MASA, Mukul SA, Hossain MK. 2008. Effects of inorganic fertilizers on biological nitrogen fixation and seedling growth of some agroforestry trees in Bangladesh. J Fores Res 19 (4) 3030-306. DOI: 10.1007/s11676-008-0054-z

Vondráčková S, Szaková J, Drábek O, Tejnecky V, Hejcman M, Müllerová V, Tlustoš P. 2015. Aluminum uptake and translocation in Al hyperaccumulator Rumex obtusifolius is affected by lowmoleucarl-weight organic acids content and soli pH. Plos ONE. 10 (4): e0123351. DOI: 10.1371/journal.pone.0123351

Wang JW, Kao CH. 2004. Reduction of aluminum-inhibited root growth of rice seedlings with supplemental calcium, magnesium and organic acids. Crop Environ Bioinform 1: 191-8.

Wang P, Bi S, Han W. 2006. Aluminum tolerance of two wheat cultivars (Brevor and Atlas66) in relation to their rhizosphere $\mathrm{pH}$ and organic acids exuded from roots. J Agric Food Chem 54 (26): 10033-10039. DOI: $10.1021 /$ jf0611769.

Washa M, Bini C, Fontana S, Wahsha A, Zilioli D. 2012. Toxicity assessment of contaminated soils from a mining area in Northeast Italy by using lipid peroxidation assay. J Geochem Explor 113: 112117. DOI: 10.1016/j.gexplo.2011.09.008.

Widyastuti SM, Harjono, Surya ZA. 2013. Initial infection of Falcatria moluccana leaves and Acacia mangium phyllodes by Uromycladium tepperianum fungi in a laboratory trial. J Manajemen Hutan Tropika 19 (3): 187-193. DOI: 10.7226/jtfm.19.3.187.

Xiao XX, Yang ZW, Zhong R, Chen L. 2003. Effect of aluminum stress on cell ultrastructure of leaf and root of longan. Sci Silvae Sin 23: 5863.

Yamamoto Y, Kobayashi Y, Devi SR, Rikiishi S, Matsumoto H. 2002. Aluminum toxicity is associated with mitochondrial dysfunction and the production of reactive oxygen species in plant cell. Plant Physiol 128: 63-72. DOI:10.1104/pp.010417

Yang M, Tan L, Xu Y, Zhao Y, Cheng F, Ye S, Jaing W. 2015. Effect of low ph and aluminum toxicity on the photosynthetic characteristics of different fast-growing eucalyptus vegetatively propagated clones. PLoS ONE 10 (6): e0130963. DOI: 10.1371/journal.pone.0130963.

Yu M, Shen RF, Liu J, Chen R, Xu M, Yong Y, Xiao H, Wang H, Wang H-Y, Wang C. 2009. The role of root border cells in aluminum resistance of pea (Pisum sativum) grown in mist culture. J Plant Nutr Soil Sci 172 (4): 528-534. DOI: 10.1002/jpln.200800039.

Yu HN, Liu P, Wang ZY, Chen WR, and Xu GD. 2011. The effect of aluminum treatments on the root growth and cell ultrastructure of two soybean genotypes. Crop Prot 30 (3): 323-338. DOI: 10.1016/j.cropro.2010.11.024.

Yuskianti V, Shiraishi S. 2017. Genetic diversity of sengon (Falcataria moluccana (Miq.) Barneby \& J.W.Grimes) Revealed using single nucleotide polymorphism (SNP) markers. Intl J For Res 4 (2): 85-94. 